\title{
EUROKOD 7 JAKO ELEMENT W SYSTEMIE BEZPIECZEŃSTWA BUDOWLI
}

\author{
Włodzimierz Brząkała ${ }^{\boxplus}$ \\ Wydział Budownictwa Lądowego i Wodnego, Politechnika Wrocławska, Wrocław
}

\begin{abstract}
STRESZCZENIE
Omówiono różne czynniki mające wpływ na geotechniczne bezpieczeństwo budowli, począwszy od fazy koncepcyjnej aż po monitoring powykonawczy, oraz podkreślono dużą rolę czynnika losowego. Przedstawiono założenia, oczekiwania i praktyczne trudności związane z wprowadzeniem normy europejskiej EN 1997, w tym trudności w stosowaniu koncepcji częściowych współczynników bezpieczeństwa. Planowane wydanie trzeciej części Eurokodu 7 może znacznie poprawić jakość normy i tym samym zwiększyć niezawodność projektowania geotechnicznego.
\end{abstract}

Słowa kluczowe: błędy w geotechnice, bezpieczeństwo geotechniczne budowli, podejście obliczeniowe, aktualizacja normy

\section{WSTĘP}

Trzecia sesja w trakcie XVIII Krajowej Konferencji Mechaniki Gruntów i Inżynierii Geotechnicznej zgromadziła kilkanaście prac o szerokim spektrum tematycznym, koncentrujących się wokół ogólnej tematyki „Zagrożenia i zabezpieczanie budowli. Aktualne problemy badawcze, wyzwania i realne możliwości”. Artykuły te, omówione krótko w pracy Brząkały (2018), stanowią inspirację do ogólniejszej analizy czynników wpływających na geotechniczne bezpieczeństwo budowli, w tym do odniesienia się do normy Eurokod 7.

Najlepszych informacji na temat zagrożeń (które bynajmniej nie są wirtualne) dostarcza analiza awarii geotechnicznych, a mówiąc ogólniej - analiza błędów geotechnicznych. Bardzo przydatne w tym celu są powszechnie znane publikacje, np. Rosiński (1978), Wysokiński (2007). Chociaż te analizy nie obejmują najnowszych technologii fundamentowych, nowych trendów w posadawianiu i nowoczesnej metodyki badania podłoża, to jednak nie wpływa to znacząco na ogólną klasyfika- cję przyczyn zagrożeń $i$ kształtowanie się proporcji między nimi. Aktualnym uzupełnieniem są specjalistyczne konferencje poświęcone awariom budowlanym, wyodrębnione sesje geotechniczne czy np. szczegółowe dyskusje panelowe na temat konkretnych spektakularnych katastrof geotechnicznych (Leonards, 1987).

Głównymi elementami w klasyfikacji zagrożeń geotechnicznych są:

- chybiona wstępna koncepcja inwestora/architekta/ /projektanta,

- niewystarczające lub wadliwe rozpoznanie podłoża gruntowego,

- niewłaściwe modele obliczeniowe,

- nieprawidłowy dobór wartości parametrów modelu obliczeniowego,

- wadliwa prognoza zjawisk geotechnicznych i nieprzewidziane zmiany warunków,

- błędy ludzkie w projektowaniu i wykonawstwie,

- brak niezależnej kontroli lub jej słaba jakość (w fazie projektowania i wykonawstwa),

- błędne postępowanie w sytuacjach awaryjnych.

\footnotetext{
$\bowtie_{\text {wlodzimierz.brzakala@pwr.edu.pl }}$
} 
Wyzwania i realne możliwości w zakresie redukcji zagrożeń to niekoniecznie użycie najnowszej aparatury badawczej czy wyrafinowanych metod numerycznych. Oceniając problem z pewnego dystansu, poprawę niezawodności w geotechnice można najszybciej i najprościej osiagnać poprzez podniesienie ogólnego poziomu świadomości oraz wiedzy geotechnicznej, dobry system norm i przede wszystkim eliminowanie możliwości popełniania „błędów grubych” (odpowiedni system kontroli).

\section{Kilka przykładów:}

Chybiona wstępna koncepcja inwestora/architekta/projektanta. Jeśli budynek biurowy (3 kondygnacje podziemne i 5 kondygnacji naziemnych) w miejscowości A okazał się sukcesem budowlanym, to wcale nie wynika stąd, że podobny projekt konstrukcyjny będzie równie dobry w nieodległej miejscowości $\mathrm{B}$, ale w ,gorszych” warunkach gruntowo-wodnych; na pewno warto wykazać się elastycznym podejściem i rozważyć koncepcję może np. 2 kondygnacji podziemnych i 6 kondygnacji naziemnych (o ile miejscowy plan zagospodarowania przestrzennego nie stoi temu na przeszkodzie); błędnej koncepcji nie da się już potem „uratować”, a w każdym razie nie są to zadania proste i tanie; ryzykowne może okazać się również stosowanie nowych technologii wzmacniania podłoża bez wieloaspektowego sprawdzenia tej technologii w skali naturalnej - w tym w odpowiednio długiej perspektywie czasowej i w warunkach nieodbiegających od sytuacji projektowej; w dobie bliskich już lotów załogowych na Marsa konserwatyzm źle się kojarzy, ale w rozwiązaniach geotechnicznych chyba lepiej sprawdza się powolna ewolucja niż rewolucja.

Niewystarczajace lub wadliwe rozpoznanie podłoża gruntowego. Na temat „oszczędności inwestorów” na badaniach podłoża, które pochłaniają znikomą część kosztu całej inwestycji, napisano już niemal wszystko; nie są częste sytuacje, aby zlecano np. specjalistyczne badania $\mathrm{w}$ kierunku uzupełnienia/doprecyzowania rozpoznania podłoża - wobec pojawiających się wątpliwości w fazie projektowania (nie należy mylić tej sytuacji z dodatkowymi badaniami wykonywanymi przez duże firmy projektowo-wykonawcze przed złożeniem oferty); jeśli problem będzie w ogóle dostrzeżony, to duże rozrzuty danych zapewne skończą się zwiększeniem marginesu bezpieczeństwa i w sumie wzrostem kosztu inwestycji; o tych okolicznościach „oszczędny” inwestor może w ogóle się nie dowiedzieć, a dodatkowe badania mogłyby per saldo znacznie obniżyć koszty, np. poprzez odstapienie od zakładanego wzmocnienia podłoża lub stosowania posadowienia pośredniego (Wysokiński, 2007); za potencjalne zagrożenie dla jakości rozpoznania podłoża należy też uznać brak stałego kontaktu pomiędzy geotechnikiem-dokumentatorem a inżynierem-konstruktorem, przede wszystkim na wczesnych etapach przygotowania inwestycji, ale również i później, przy realizacji wykopów i elementów posadowienia.

Niewtaściwe modele obliczeniowe. W ogólnej ocenie niezawodności projektowania trudno przecenić rolę dobrej, krótkiej i jasno zredagowanej normy, w której reguluje się sprawy m.in. modeli obliczeniowych - na podstawie dobrze sprawdzonych w praktyce doświadczeń; zredagowanie dobrego aktu prawnego (normatywnego) to wielka sztuka - nie tylko w zakresie meritum, ale w równym stopniu w zakresie percepcji, unikania niejednoznaczności oraz luk, nieporozumień interpretacyjnych, kolizji oznaczeń itp.; często potrzebna jest współpraca $\mathrm{z}$ (pod)zespołem złożonym z „niespecjalistów”, ponieważ specjaliści nie dostrzegają ,pułapek”, które pozostawiają w tworzonych przepisach (Ratajczak, 1988).

Nieprawidłowy dobór wartości parametrów modelu obliczeniowego. Dobór wartości parametrów użytych w modelu obliczeniowym bezpośrednio rzutuje na jakość projektowania, chociaż popularne powiedzenie „Garbage in - Garbage out” jest chyba za mocnym określeniem; najsłynniejsze osuwisko warszawskie sprzed 20 lat - złamanie się ściany szczelinowej przy ul. Puławskiej/Chocimskiej jest tu dobrym przykładem, jak bardzo mogą się różnić parametry wytrzymałościowe przyjmowane przez różne zespoły ekspertów; warto odnotować, że do parametrów modelu obliczeniowego zaliczyć należy również współczynniki bezpieczeństwa, ale w tym większe znaczenie ma samo ich uwzględnienie od sposobu określania wartości (podejście obliczeniowe); można odnieść wrażenie, że podłoże budowlane „toleruje” pojedyncze lokalne błędy geotechniczne, których można byłoby doszukać się niemal w każdym procesie inwestycyjnym - „nie toleruje” natomiast nakładających się 
wielu błędów o podobnej naturze i zlokalizowanych w tym samym miejscu, a przede wszystkim „błędów grubych", których trzeba najbardziej się wystrzegać.

Wadliwa prognoza zjawisk geotechnicznych i nieprzewidziane zmiany warunków. Nieprzewidziane zmiany warunków należy odróżnić od zmian nieprzewidywalnych; tych drugich generalnie nie da się prognozować, jak np. awarii budynku A w wyniku nieprawidłowo prowadzonych robót $\mathrm{i}$ katastrofy na sąsiedniej działce B (choć odpowiedni nadzór i monitoring może być bardzo pomocny); przewidywanie zmian sytuacji gruntowo-wodnej nie zawsze wymaga dużej wiedzy specjalistycznej - wiadomo, czym się może skończyć bardzo intensywne pompowanie wody ze studni/z wykopu, która jest mętna i wynosi drobne frakcje pylaste, jakie zjawiska reologiczne wystapia w kotwach trwałych, jaki może być wpływ warstwy torfów na nośność pali itp.; szczególną rolę odgrywa prognoza przyrostu obciążeń, w tym prędkości wzrostu obciążenia w stosunku do zdolności filtracyjnych podłoża.

Btędy ludzkie $w$ projektowaniu $i$ wykonawstwie. Błędy ludzkie są dominująca przyczyną katastrof i awarii, w szczególności w budownictwie - w różnych źródłach podaje się od kilkunastu procent do ponad $70 \%$ ich udziału; te ogromne rozbieżności wynikają z niejasnych, fragmentarycznych, a czasem może zafałszowanych dokumentacji powypadkowych oraz braku precyzji sformułowania „błąd ludzki” - jest nim zapewne pomylenie wytrzymałości maksymalnej i rezydualnej czy np. niewłaściwa kalibracja inklinometru (odczyt zerowy), ale już niekoniecznie wyinterpretowanie przebiegu granicy między warstwami gruntów; lepszych danych dostarcza analiza przyczyn wypadków lotniczych, zazwyczaj bardzo skrupulatnie badanych w interesie różnych zainteresowanych stron (szacunki wskazują na co najmniej $75 \%$ udziału błędów ludzkich), a w przypadku wypadków samochodowych jest to jeszcze większy odsetek; oczywiście, błędy wykonawcze mogą zawsze zniweczyć wysiłki związane $\mathrm{z}$ wiarygodnym rozpoznaniem podłoża i zaprojektowaniem niezawodnego posadowienia.

Brak niezależnej kontroli lub jej słaba jakość ( $w$ fazie projektowania $i$ wykonawstwa). Nieprzypadkowo projekt budowlany musi być sprawdzony przez uprawnioną osobę, ale dziwi, że w przypadku bardziej specjalistycznego projektu wykonawczego takiego obowiązku prawnego już nie ma; bardzo ważna jest funkcja inspektora nadzoru w procesie budowlanym, w tym nadzoru geotechnicznego, a zajmują się tym w sposób bardzo profesjonalny wyspecjalizowane firmy; nierzadko inwestorzy zlecają niezależnym specjalistom opracowanie koreferatu projektu, jego poszczególnych rozwiązań lub koncepcji - i to również na bardzo wczesnych etapach inwestycji - niepokoi, że najrzadziej postępują tak władze publiczne, dla których korzystanie z doradztwa instytutów naukowo-badawczych i z potencjału wydziałów budownictwa (lub pokrewnych) w regionie powinno być standardem; generalnie jednak, należy odnotować w tym zakresie duży postęp po transformacji ustrojowej w Polsce, a monitoring terenu budowy i jego otoczenia (również powykonawczy) ma należną rangę i znacznie redukuje zagrożenia.

Btędne postępowanie $w$ sytuacjach awaryjnych. $\mathrm{W}$ przypadku awarii geotechnicznych konieczne jest wnikliwe, a przy tym relatywnie szybkie, rozważenie skutków podejmowanych działań ratowniczych (podobnie jak przy udzielaniu pierwszej pomocy medycznej), ponieważ łatwo jest o pogorszenie stanu awaryjnego; pierwsze próby stabilizacji krzywej wieży w Pizie, te sprzed wielu dziesiątek lat, są tego dobrym przykładem.

Klamrą spinająca niemal wszystkie z wymienionych czynników zagrożenia $\mathrm{w}$ geotechnice jest europejska norma Eurokod 7 (EC7, PN-EN 1997); jest ona wyzwaniem i aktualnym problem badawczym, już wkrótce dla trzeciego pokolenia geotechników.

\section{ZAŁOŻENIA I TWORZENIE EUROKODÓW}

Koncepcja europejskiego systemu norm budowlanych pojawiła się ok. 45 lat temu (Orr, 2010; Kłosiński, 2013; Cichy, Lechowicz i Garbulewski, 2017), ale w zakresie geotechniki zwykle wymienia się 1980 rok, w którym międzynarodowe stowarzyszenie ISSMGE powołało podkomitet ds. Eurokodu 7, kierowany przez prof. Nielsa Krebsa Ovesena. Ogólny kształt Eurokodu 7 (Draft Model for Eurocode 7) był gotowy w połowie 1987 roku, po 22 spotkaniach półoficjalnego komitetu redakcyjnego. Jednym z pierwszych krajów, gdzie zaprezentowano tę koncepcję EC7, była 
Polska. W październiku 1987 roku odbywała się we Wrocławiu VIII Krajowa Konferencja Mechaniki Gruntów i Fundamentowania, a honorowym gościem konferencji był właśnie prof. Krebs Ovesen, który wystąił z obszernym wykładem na temat Eurokodu 7.

Sama Europejska Wspólnota Gospodarcza (wówczas obowiązująca nazwa) była wtedy dla mieszkańców znad Wisły, Odry i Warty tworem dosyć egzotycznym, a koncepcja współpracy naukowej i normalizacji o takim zasięgu - tym bardziej. Referent, nazywany żartobliwie „Mr Eurocode”, z wielkim przekonaniem mówił o korzyściach płynących z Eurokodu 7, a szczególnie podkreślał mocne podstawy teoretyczne tej normy, czyli probabilistyczną metodę stanów granicznych, promowaną m.in. przez duńską szkołe niezawodności i bezpieczeństwa budowli. Profesor Krebs Ovesen zaskoczył większość słuchaczy zakresem i rozmachem logistycznym przedsięwzięcia, ale od strony merytorycznej to już nie tak bardzo zaskoczył, bo np. aktualna wówczas norma PN-81/B-03020. Posadowienie bezpośrednie budowli zawierała te „rewolucyjne koncepcje” może nawet w $80-90 \%$ - w zakresie, którego ta norma dotyczyła.

Najpierw ukazał się półoficjalny raport w grudniu 1987 roku, który zyskał uznanie Komisji Europejskiej. W efekcie zespół redakcyjny uzyskał oficjalny status Drafting Panel for Eurocode 7, a w 1989 roku działał już oficjalnie w strukturach CEN (Orr, 2010). Od pojawienia się pierwszej wersji wydrukowanej ENV w 1994 roku, przez kilka kolejnych lat wersje „próbne” Eurokodów występowały równolegle z normami krajowymi, wpływając nierzadko na ich modyfikacje. Za date powszechnego obowiązywania Eurokodów w krajach unijnych przyjmuje się 1 kwietnia 2010 roku, co w Polsce ma umocowanie prawne w odpowiednim rozporządzeniu ministra infrastruktury, wycofującym polskie normy wymienione w załączniku. Urzędowe wycofanie polskich norm (a ściślej zastąienie ich Eurokodami) nie jest równoważne z zakazem ich używania, o ile nie są one sprzeczne z Eurokodami ${ }^{1}$. Komitet Techniczny PKN ds. Geotechniki wskazuje na potrzebę utrzymania krajowych norm projektowania, tych podstawowych (Kłosiński, 2013; Cichy i in., 2017).

W kilku krajach nie wyjaśniono jeszcze ostatecznie zakresu nadrzędności prawa unijnego $\mathrm{w}$ stosunku do prawa krajowego. Aby uniknać wątpliwości formalno-prawnych, Eurokody są zazwyczaj w całości przyjmowane przez krajowe komitety normalizacyjne jako obowiązujące normy krajowe; możliwy jest pewien (ograniczony) stopień indywidualizacji w tzw. załącznikach krajowych.

Zasadniczo Eurokodów jest 10 (od EN 1990 do EN 1999) - ale z wydzielonymi częściami pełna lista liczy obecnie 59 pozycji, wymienionych na stronie internetowej PKN. Eurokody miały chyba z założenia ukazywać się co roku, z możliwością uaktualniania w późniejszych latach. Warto jeszcze wymienić ważną normę ogólną o znaczeniu normotwórczym: ISO 2394:2015(E). General principles on reliability for structures $^{2}$, która stanowi podstawę merytoryczną znacznej części norm EC0 oraz EC1, a w następstwie wszystkich kolejnych Eurokodów.

Ogólny cel Eurokodów - podniesienie efektywności gospodarczej i konkurencyjności poprzez zniesienie przeszkód i ujednolicenie wymogów projektowych w zakresie budownictwa (Orr, 2010) - został szybko uogólniony na zagadnienia technologicznowykonawcze oraz materiałowe, skutkując powstaniem bardzo wielu specyfikacji technicznych (norm wykonawczych).

\footnotetext{
${ }^{1}$ Na stronie PKN, https://www.pkn.pl/normalizacja/sektory-normalizacji/budownictwo-i-konstrukcje-budowlane/eurokody figuruje obecnie następujący zapis

„Projektowanie konstrukcji budowlanych jest możliwe w Polsce w oparciu o:

- Polskie Normy własne/krajowe, mające od 1 kwietna 2010 r. status norm wycofanych, [...],

- Eurokody, gdyż zostały one wprowadzone w wersji polskojęzycznej wraz z Załącznikami krajowymi, [...].”.

${ }^{2}$ Polski odpowiednik PN-ISO 2394 Ogólne zasady niezawodności konstrukcji budowlanych z kwietnia 2000 roku został wycofany w 2016 roku; aktualnej wersji z 2015 roku jeszcze nie przetłumaczono.
} 


\section{EWOLUCJA EC7}

Cele PN-EN 1997 są oczywiście zgodne z celem ogólnym Eurokodów, a dodatkowo zakładano (Orr, 2010):

- wypracowanie jednolitego podejścia, spójnego z pozostałymi Eurokodami, m.in. w zakresie metodyki określania wartości charakterystycznych parametrów podłoża lub wartości obliczeniowych, czy częściowych współczynników bezpieczeństwa,

- wypracowanie kompromisu wśród europejskich geotechników i ujednolicenie metod obliczeniowych w zakresie stanów granicznych różnych konstrukcji geoinżynieryjnych,

- zgodność EN 1997 z „bazowymi” normami EN 1990 oraz EN 1991, w tym operowanie częściowymi współczynnikami bezpieczeństwa do parametrów materiałowych oraz do granicznego oporu.

Twórcy Eurokodów od początku zdawali sobie sprawę z dużych „oporów materii” w zakresie wdrażania do projektowania metod probabilistycznych (ang. Probability-Based Design Methods - P-BDM). Paradoksalnie, ale P-BDM powinny być szczególnie atrakcyjne $\mathrm{w}$ geotechnice - w której akurat element losowości odgrywa chyba rolę największą, już począwszy od etapu rozpoznania podłoża i ustalania danych.

Rzeczywiście istnieją obawy, że w projektowaniu sytuacja się odwróci i kluczowa dla sprawy niezawodność obliczeń będzie zdominowana przez obliczanie niezawodności; chyba dlatego wymyślono nazwę metody pół-probabilistyczne, które operują wartościami charakterystycznymi i częściowymi współczynnikami bezpieczeństwa.

Szybko okazało się, że z EC7 będą większe kłopoty niż z pozostałymi Eurokodami; w efekcie połowa EC7 (cała część 2) dotyczy badania podłoża budowli jako materiału - sytuacja dosyć nietypowa w systemie Eurokodów, które generalnie nie dotyczą metodyki badań materiałowych.

Resztę EC7 (część 1) stanowią Zasady ogólne, co jest mylącą nazwą w kontekście EC7-2, gdzie też są przecież tylko zasady ogólne i wyłącznie załączniki informacyjne. Oznacza to, że nie ma w Eurokodzie 7 głównej części projektowej (pomijając załączniki o charakterze informacyjnym) - wbrew nazwie tej normy Projektowanie geotechniczne ${ }^{3}$. Można odnieść wrażenie, jakby prace nad EC7 zostały niedokończone i pod presją terminów „spięto” to, co było bardziej lub mniej gotowe. Powstało wprawdzie wiele artykułów i nawet książek z cyklu „,co Autorzy EC7 mieli na myśli", ale nie mają one mocy prawnej i w niektórych szczegółach zawierają treści kontrowersyjne - szczególnie dla czytelników z innych krajów niż autorzy tych publikacji.

Dużo kompetentnych treści na ten temat można znaleźć np. w pracy Kłosińskiego (2013), w której omówiono wady i zalety EC7-1 oraz EC7-2 - uwagi te do dziś pozostają aktualne.

Istniejące braki mają być uzupełnione do 2019 ro$\mathrm{ku}$, niezależnie od usuwanych na bieżąco usterek mniejszej wagi.

\section{SKĄD TYLE TRUDNOŚCI?}

Oprócz oczywistych trudności związanych z wiarygodnością rozpoznania warunków gruntowo-wodnych $\mathrm{i}$ ich zmian w czasie czy skomplikowanego zachowania się podłoża budowli występują problemy całkiem prozaiczne (rys. 1).

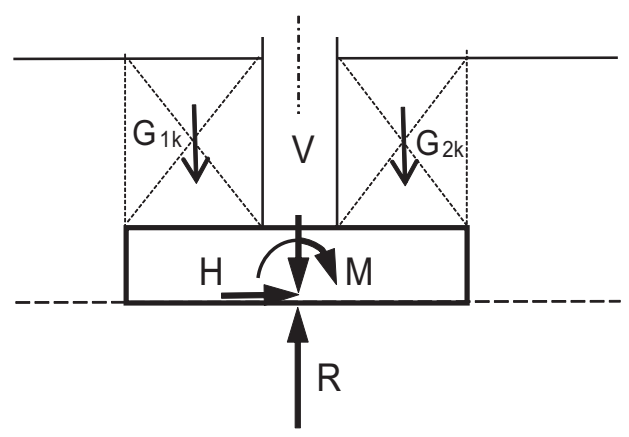

Rys. 1. Stabilizujący wpływ ciężaru własnego gruntu zasypowego w warunku obliczeniowym nośności $V_{d} \leq R_{d}$

Fig. 1. Stabilizing role of a backfill weight in the ULS condition $V_{d} \leq R_{d}$

\footnotetext{
${ }^{3}$ Paradoksalnie o projektowaniu pali (określaniu ich nośności) więcej konkretów można odnaleźć w EC7-2 czy nawet w EC3-5 niż w EC7-1.
} 
Rozpatrzmy poglądowy przykład ławy fundamentowej na rysunku 1 . Zależnie od proporcji sił oraz wytrzymałości gruntu pod ławą w pewnych sytuacjach istotny może okazać się stabilizujący wpływ ciężaru zasypki na fundamencie. Generalnie Eurokod 7 odstępuje od traktowania ciężaru własnego gruntu jako wielkości losowej, co jest słuszne, ponieważ ta zmienność nie przekracza kilku procent (a w dodatku ulega przestrzennemu uśrednieniu). Jednak ciężar własny konstrukcji też nie podlega większym wahaniom, a mimo wszystko zastosowanie ma współczynnik $\gamma_{G}=1,35$. Prawdopodobnie tak duża wartość $\gamma_{G}$ wynika z wpływu uproszczeń w schematach (statycznie niewyznaczalnych) przekazywania obciążeń stałych z konstrukcji na poszczególne fundamenty, czyli zawiera „wbudowany” współczynnik bezpieczeństwa zastosowany do modelu obliczeniowego konstrukcji ${ }^{4}$. Ciężar zasypki na fundamencie (rys. 1) może jednak w pewnych sytuacjach stanowić istotną część pionowego obciążenia $V$ i nie widać czysto formalnego uzasadnienia, aby w warunku obliczeniowym nośności $V_{d} \leq R_{d}$ (GEO, EC7-1) postępować inaczej, niż uwzględniając $G_{d}=1,35 \cdot G_{1 k}+1,35 \cdot G_{2 k} \mathrm{~W}$ pionowym obciążeniu wypadkowym $V_{\mathrm{d}}$.

Jeśli chodzi o nośność $R_{d}$, to bardzo dobrym rozwiązaniem jest wprowadzone podejście obliczeniowe GEO-DA2*:

$$
V_{d}<R_{d}=\frac{R_{k}}{\gamma_{R}}
$$

w którym nośność charakterystyczna $R_{k}$ zależy po prostu od wartości charakterystycznych $G_{1 k}$ oraz $G_{2 k}$ i cały „problem” od razu znika.

Gdyby było inaczej, to prawidłowy dobór częściowych współczynników bezpieczeństwa w celu obliczenia nośności $R_{d}$ mógłby budzić wątpliwości i mało sensownie zwiększać liczbę schematów obliczeniowych do rozważenia, ponieważ ciężary $G_{1}$, $G_{2}$ mają wpływ nie tylko na obciążenia $V$, ale też na nośność $R$, czyli zarówno na prawą, jak i na lewą stronę warunku stanu granicznego. W tym przypadku z rysunku 1 należałoby - być może - sprawdzić trzy sytuacje obliczeniowe:

1) przyjęcie $1,35 \cdot G_{1 k}$ oraz $1,35 \cdot G_{2 k}$, idąc konsekwentnie za obliczeniami $V_{d}$,

2) przyjęcie $1,00 \cdot G_{1 k}$ oraz $1,35 \cdot G_{2 k}$ może okazać się racjonalne, ponieważ wzrośnie w ten sposób moment obliczeniowy $M_{d}>0$, który poprzez mimośród $e_{B}>0$ obniża nośność $R_{d}$,

3) przyjęcie $1,00 \cdot G_{1 k}$ oraz $1,00 \cdot G_{2 k}$ może również okazać się racjonalne, ponieważ zmaleje $\mathrm{w}$ ten sposób wypadkowa $V_{d}$ i w następstwie wzrośnie odchylenie obciążenia wypadkowego od pionu (przy założeniu stałej wartości siły poziomej $H_{d}$ ), co obniża nośność $R_{d}$.

Dzięki podejściu obliczeniowemu DA2* nie ma potrzeby zajmowania się tymi udziwnionymi przypadkami.

Sprawa bezpiecznej oceny czynnego obciążenia po lewej stronie warunku stateczności też nie jest do końca oczywista. Rozpatrzmy przykładowo stateczność GEO na przesunięcie $T_{d} \leq T_{f d}$ wspornikowej ściany oporowej w schemacie Rankine'a (parcie gruntu $E_{a}$ na wirtualnej pionowej powierzchni $\mathrm{AB}$ jest równoległe do powierzchni terenu).

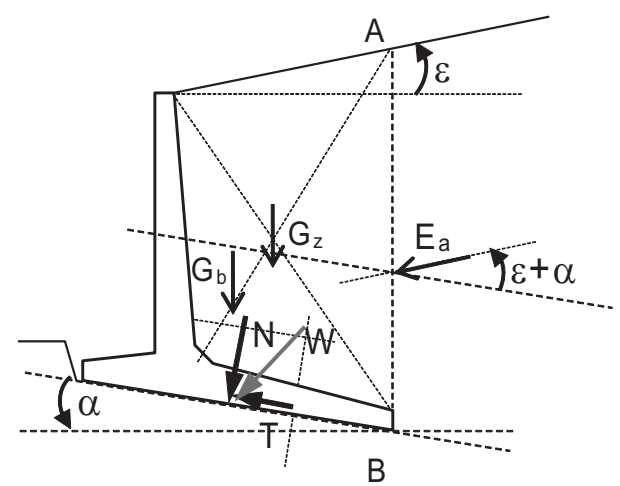

Rys. 2. Działające obciążenia stałe

Fig. 2. Acting permanent loads

Właśnie ciężar jest tutaj jedynym źródłem obciążeń, a podstawowym oddziaływaniem jest wektorowa siła wypadkowa $\underline{W}=\underline{N}+\underline{T}$ sprowadzona do (nachylonej) podstawy płyty fundamentowej, pochodząca

${ }^{4}$ Czyli jest on niepotrzebnie tak duży, gdy cała konstrukcja spoczywa na jednej płycie fundamentowej. 
od parcia gruntu $E_{a}$, ciężaru zasypki $G_{z}$ oraz ciężaru ściany $G_{\dot{s}}$ :

$$
\begin{aligned}
& N=E_{a} \cdot \sin (\varepsilon+\alpha)+\left(G_{\dot{\mathrm{s}}}+G_{z}\right) \cdot \cos \alpha \\
& T=E_{a} \cdot \cos (\varepsilon+\alpha)-\left(G_{\mathrm{s}}+G_{z}\right) \cdot \sin \alpha
\end{aligned}
$$

Pomijając imperfekcje wymiarowe, w tym przypadku są dwa podstawowe źródła losowości: ciężar objętościowy gruntu oraz jego kąt tarcia wewnętrznego.

Podejście obliczeniowe GEO-DA2* w postaci $T_{d}<T_{f d}=\frac{T_{f k}}{\gamma_{R}}$ eliminuje problem częściowych współczynników bezpieczeństwa dla składowej $N$, ponieważ opór podłoża $T_{f k}$ zależy od jej wartości charakterystycznej. Watpliwości pozostają w sprawie siły przesuwającej $T_{d}$ :

1) użycie jednego współczynnika do wypadkowych efektów oddziaływań

$$
\begin{aligned}
& T_{d}=1,35 \cdot\left[E_{a} \cdot \cos (\varepsilon+\alpha)-\left(G_{b}+G_{z}\right) \cdot \sin \alpha\right] \\
& \text { czyli } \\
& T_{d}=1,35 \cdot\left[E_{a} \cdot \cos (\varepsilon+\alpha)\right]-1,35 \cdot\left[\left(G_{b}+G_{z}\right) \cdot \sin \alpha\right]
\end{aligned}
$$

sprawia wrażenie, że - wbrew ogólnym zasadom - powiększa się o 35\% składnik stabilizujący pochodzący od $G$,

2) użycie zróżnicowanych współczynników do poszczególnych oddziaływań „na zasadzie obwiedni”:

$T_{d}=1,35 \cdot\left[E_{a} \cdot \cos (\varepsilon+\alpha)\right]-1,00 \cdot\left[\left(G_{b}+G_{z}\right) \cdot \sin \alpha\right]$

budzi zastrzeżenia od strony fizycznej, ponieważ zarówno $E_{a}$, jak i $G_{z}$ pochodzą od tego samego gruntu - jednorodnej zasypki, identycznej po obu stronach wirtualnej ściany AB.

Oczywiście pominięcie współczynnika $\gamma_{G}=1,35$ jest tutaj niemożliwe, bo przy bardzo małej wartości współczynnika $\gamma_{R}=1,1$ zapas bezpieczeństwa byłby niezwykle mały, niespójny ze współczynnikiem $\gamma_{M}=1,25$ przyjmowanym przy innej okazji.

Podobnych paradoksów można podać więcej w stateczności skarp w sposób jeszcze bardziej jaskrawy, gdyż ciężar własny powoduje zarówno siły destabilizujące, jak i stabilizujące.

\section{PODSUMOWANIE}

1. Występuje sprzężenie lewej i prawej strony w warunku stanu granicznego nośności, które można uznać za praprzyczynę trudności w ocenie ULS za pomocą częściowych współczynników bezpieczeństwa (nie tylko w tych przykładach).

2. Przyjęte podejście obliczeniowe GEO-DA2* w sposób racjonalny bardzo upraszcza sprawę; bez tego uproszczenia trudno byłoby bronić się przed zarzutem, że norma EC7 wiele miejsca poświęca przypadkom oderwanym od praktyki projektowej, które sama generuje; odejście od częściowych współczynników bezpieczeństwa radykalnie poprawia sytuację.

3. Podejście obliczeniowe DA2* oddala się od pierwotnej koncepcji częściowych współczynników bezpieczeństwa; współczynnik efektów oddziaływań $\gamma_{R}$, to już trochę taki ,,pół-ogólny” współczynnik bezpieczeństwa.

4. Przez analogię do współczynnika $\gamma_{R}$, gdyby oddziaływaniom destabilizującym $E_{\text {dest } ; k}$ przypisać też pewien uogólniony współczynnik $\gamma_{E}$ (zapewne o wartości pośredniej między $\left.\gamma_{G}=1,35 \mathrm{i} \gamma_{Q}=1,50\right)$, to warunek obliczeniowy ULS

$\gamma_{E} \cdot E_{\text {dest } ; k}=E_{\text {dest } ; d} \leq R_{\text {stab;d }}=\frac{R_{\text {stab; } ;}}{\gamma_{R}}$

miałby postać

$$
E_{\text {dest } ; k} \leq \frac{R_{\text {stab } ; k}}{\gamma_{E} \cdot \gamma_{R}}=\frac{R_{\text {stab; } ;}}{\gamma_{o}}
$$

co sprowadza się do ogólnego współczynnika bezpieczeństwa $\gamma_{o}$, tyle że przedstawionego w postaci dwóch współczynników „pół-ogólnych” (faktoryzacja $\gamma_{o}=\gamma_{E} \cdot \gamma_{R}$ ).

\section{STAN OBECNY}

Wracając do trzech pierwotnych założeń w rozdziale „Ewolucja EC7”, można przeanalizować, w jakim stopniu udało się zrealizować wymienione cele 1-3. Zdaniem autora tym wyzwaniom sprostano dotychczas co najwyżej w połowie. 
1. Wypracowanie jednolitego podejścia

Jeśli chodzi o wartości charakterystyczne $X_{k}$ parametrów geotechnicznych, czy wartości obliczeniowe $X_{d}$, to szanse na unifikację od początku były niewielkie podłoże budowlane nie jest materiałem powstającym w kontrolowanych warunkach w wytwórni i standardowy kwantyl 5\% jest bezużyteczny (za mała liczba próbek w jednym rejonie subiektywnie uznanym za statystycznie jednorodny, za duże rozrzuty wyników); lepsze własności ma po prostu wartość średnia $X_{m}$, ponieważ zachowanie się podłoża gruntowego, to pewien efekt uśredniony $z$ wielu obszarów współpracujących z konstrukcją. Wartości średniej $X_{m}$ nie można jednak uznać za „ostrożne” szacowanie parametru. W przypadku parametru o stabilizującym wpływie, nakładają się na siebie dwie przeciwne tendencje:

- konieczność zmniejszania wartości parametru na skutek wewnętrznej niejednorodności ośrodka,

- konieczność zwiększania zmniejszonej wartości tego parametru na skutek przestrzennej autokorelacji i korelacji wzajemnej parametrów w podłożu budowlanym, szczególnie korelacji ujemnej.

Rozsądna jest propozycja Schneidera, omówiona np. w pracy Brząkały (2013), aby wartość charakterystyczną $X_{k}$ parametru wyrażać za pomocą współczynnika redukcyjnego $\Gamma$, a konkretnie:

$$
X_{k}=X_{m} \cdot(1 \pm 1,65 \cdot \Gamma \cdot v), \Gamma=\sqrt{\frac{\delta}{L}} \leq 1
$$

gdzie:

$v$ - współczynnik zmienności punktowej $v=\sigma / \mu[-]$;

$\delta$ - skala fluktuacji parametru w podłożu [m],

$L$ - długość linii poślizgu w stanie granicznym [m].

Współczynnik zmienności $v$, będący ilorazem odchylenia standardowego $\sigma$ oraz dodatniej wartości oczekiwanej $\mu$, jest w praktyce zastępowany ilorazem wartości estymatora odchylenia standardowego oraz wartości średniej z próby. Skala fluktuacji $\delta$ określa przestrzenną korelację wyników, tj. korelację wartości pomiędzy punktami np. w tej samej odległości. Przykładowo, jeśli w pewnej warstwie geotechnicznej przyjąć liniowy trend wzrostu z głębokością oporu stożka $q_{c}$, to każdy pomiar oporu stożka wyznacza pewną losową linię, która oscyluje („faluje”) wokół tego trendu; długość tej „fali”, czy też średnia odległość między kolejnymi punktami przecięcia z linią trendu, służy do określenia skali fluktuacji - w przypadku małej odległości mówi się o losowej funkcji „,szybkozmiennej” $i$ jest to korzystny przypadek znacznego wythumienia losowych niejednorodności podłoża.

Warto odnotować (Brząkała, 2013), że w przypadku parametru $X$ o roli stabilizującej i przy racjonalnym zestawie parametrów $\Gamma=0,3$ oraz $v=$ $=0,2$, otrzymuje się $X_{k}=X_{m} \cdot(1-1,65 \cdot 0,3 \cdot 0,2)=$ $=X_{m} \cdot 0,9 ; \mathrm{w}$ przypadku „małych” stóp fundamentowych (a zatem ,małych" wartości parametru $L$ ) racjonalne jest $\Gamma=0,6$, a wtedy $X_{k}=X_{m} \cdot(1-1,65 \cdot 0,6 \cdot 0,2)=$ $=X_{m} \cdot 0,8$; otrzymany przedział $0,8-0,9$ dobrze koresponduje z PN-81/B-03020.

Należy też korygować wartość charakterystyczną w zależności od liczebności próby, czyli operować przedziałami ufności. Doświadczenie geotechnika jest często w kolizji ze statystyka - jeśli dokumentator uzna jakiś wynik badań gruntu za tzw. gruby błąd (ang. outliner), to jego odrzucenie w małej populacji w sposób znaczący wpływa na wynik statystyczny $X_{m}$ oraz $v$. Co ważniejsze jednak, wartości $X_{m}$ są wyprowadzone z konkretnej metody wyznaczania parametru, np. $\operatorname{tg} \varphi^{\prime}$ za pomocą oporu stożka $q_{c}$ z sondowania CPTU, a przejście od $q_{c}$ do $\operatorname{tg} \varphi^{\prime}$ jest obarczone pewnym błędem przybliżenia, dosyć subiektywnie szacowanym. Ten błąd zależy też od dokładności wyznaczania samego $q_{c}$ i gęstości opróbkowania podłoża.

Wynika stąd, że wartość charakterystyczna, jako „ostrożne" szacowanie parametru geotechnicznego, jest uznaniowa, a zatem taki sam charakter ma wynikająca z niej wartość obliczeniowa, szczególnie że częściowe współczynniki bezpieczeństwa mają też wartości uznaniowe. Jak wynika bowiem z modelu matematycznego, częściowe współczynniki bezpieczeństwa nie są stałymi (Brząkała, 2013) i cechuja się dużym rozrzutem wartości; mówiąc o stałych wartościach tych współczynników, trzeba dokonać uśrednienia $\mathrm{w}$ dosyć szerokim przedziale wartości. $\mathrm{W}$ sumie $\mathrm{z}$ naturalną niejednorodnością podłoża i losowymi warunkami pomiaru (np. oporu $q_{c}$ ) należy zestawić czynniki subiektywne:

- dobór liczby i miejsc opróbkowania podłoża, - wstępna preselekcja wyników pomiarów (np. $q_{c}$ ), 
- niejednoznaczność wyboru wzoru korelacyjnego do predykcji $\operatorname{tg} \varphi^{\prime}$ za pomoca $q_{c}$,

- subiektywna ocena skali fluktuacji i współczynnika redukcyjnego $\Gamma$ na podstawie autokorelacji pola losowego, niedopracowana metodyka uwzględniania korelacji wzajemnych pomiędzy czynnikami decydującymi o nośności,

- niejednoznaczność metodyki transformacji wyników - czy obróbce statystycznej poddawać wartości $q_{c}$, obliczyć dla nich wartość oczekiwaną $q_{c m}$ oraz odchylenie standardowe, czy też najpierw dokonać transformacji każdego wyniku $q_{c}$ na $\operatorname{tg} \varphi^{\prime}$ i dopiero wtedy wykonać obliczenia statystyczne,

- model geologiczny i geotechniczny budowy podłoża,

- dokonanie wydzielenia warstw geotechnicznych.

Nie widać, w jaki sposób wymienione czynniki subiektywne wpływają na przyjmowane do obliczeń wartość $X_{k}$ czy $X_{d}-$ a jest tych czynników więcej i mogą okazać się bardziej znaczące niż naturalna niejednorodność podłoża.

2. Wypracowanie kompromisu wśród geotechników i ujednolicenie metod obliczeniowych

Wprowadzenie swobodnego wyboru spośród trzech odmiennych podejść obliczeniowych (DA) - nazywane eufemistycznie „kompromisem” - jest odstępstwem od celów Eurokodów. Za jeden z nielicznych konkretów można uznać zestaw (bardzo wielu) współczynników przedstawionych w załączniku do EC7-1, jedynym normatywnym załączniku, który jest obowiązujący. Trudno oprzeć się wrażeniu, że powinno być odwrotnie - to właśnie wartości współczynników mogłyby być ustalane w załącznikach krajowych, a same procedury oraz modele obliczeniowe są nadrzędne w stosunku do wartości współczynników i właśnie one powinny być jednolite. Daje się zauważyć rosnącą presję na rozbudowę załączników krajowych (z czym liczono się od początku), przy której łatwo naruszyć pierwotne cele utworzenia Eurokodu 7.

3. Zgodność EN 1997 z „bazowymi” normami EN 1990 oraz z EN 1991

Główna miara niezawodności, którą jest wskaźnik niezawodności $\beta$, w ogóle nie pojawia się w EC-7, opisowym odpowiednikiem kategorii niezawodności są być może kategorie geotechniczne, ale nie jest to jednoznacznie określone; podział na:

- obciążenia, oddziaływania, efekty odziaływania $(A)$,

- parametry materiałowe gruntów $(M)$,

- opór graniczny $(R)$

jest na ogół niezasadny - w podłożu mamy zazwyczaj „trzy w jednym”, niektóre z przyjętych wartości częściowych współczynników bezpieczeństwa sa zaskakująco duże $\left(\gamma_{G}=1,35\right)$ i prawdopodobnie mają służyć uwzględnieniu niedokładności modelu obliczeniowego, choć to jest już inne zagadnienie.

Jak wykazano w pracy autora (Brząkała, 2013), standardowa metoda wyznaczenia częściowych współczynników bezpieczeństwa zgodna z PN-EN 1990 czy też ISO 2394:2015(E) ma ograniczone możliwości. Już w najprostszym warunku stanu granicznego GEO na przesunięcie ( $\mathrm{w}$ naprężeniach) $\tau \leq \tau_{f}=q_{n} \cdot \operatorname{tg} \varphi^{\prime}+c^{\prime}$, będącym funkcją liniowa zmiennej losowej $X_{1}=\operatorname{tg} \varphi^{\prime}$ oraz zmiennej losowej $X_{2}=c^{\prime}$, wskaźnik niezawodności $\beta$ zależy od deterministycznej wielkości naprężenia $q_{n}$; pożądane byłoby projektowanie na zadany poziom niezawodności np. $\beta=3,8$, ale jest to możliwe tylko przy założeniu, że $q_{n}$ zmienia się $\mathrm{w}$ małym zakresie. Co więcej, częściowe współczynniki bezpieczeństwa przy zmiennych losowych $\operatorname{tg} \varphi^{\prime}$ oraz $c^{\prime}$ nie są stałe, także zależą od deterministycznego $q_{n}$; jest to łatwe do przewidzenia, bez obliczeń: jeśli deterministyczne naprężenie normalne $q_{n}$ jest „bardzo duże”, to opór na ścinanie $\tau_{f}$ prawie nie zależy od $c^{\prime}$, czyli z małym błędem można powiedzieć, że jest tylko jedna zmienna losowa $\operatorname{tg} \varphi^{\prime}$ czy też $q_{n} \cdot \operatorname{tg} \varphi^{\prime}$; odwrotnie jest dla „bardzo małych” $q_{n}$, ale z podobnym efektem wpływ losowości tarcia wewnętrznego można wtedy pominaćc; dla „średnich” naprężeń $q_{n}$ występuje natomiast porównywalny wpływ dwóch zmiennych losowych, co tworzy nową jakość, ponieważ suma dwóch zmiennych losowych ulega zazwyczaj redukcji (zwłaszcza przy ujemnej korelacji). Wiele innych „nietypowych” wyników można znaleźć w pracy autora (Brząkała, 2013), w tym otrzymane częściowe współczynniki bezpieczeństwa dla tg $\varphi^{\prime}$, które są np. czasem bliskie wartości 2,0 a czasem mniejsze od 1,0 . 
Z tej zagmatwanej sytuacji możliwe są co najmniej trzy wyjścia, spośród tych najprostszych.

\section{Po pierwsze:}

Uporządkowanie i dopracowanie obliczeniowej metody projektowania według Eurokodu 7 od strony teorii niezawodności budowli. Tak zwane metody wyższych poziomów obliczeń niezawodności, operujące rozkładami prawdopodobieństwa, wydają się zbyt skomplikowane, ale dobrą alternatywę stanowi analiza FORM, w sumie bardzo podobna do omówionej wyżej kalibracji (Brząkała, 2013), jednak w odwróconej kolejności:

- przyjmuje się wzór, tj. funkcyjny warunek stanu granicznego $E-R=g\left(X_{1}, \ldots, X_{n}\right)=0$, z niektórymi parametrami traktowanymi jako zmienne losowe o znanych dwóch pierwszych momentach,

- wyznacza się wskaźnik niezawodności $\beta$ (PN-EN 1990) i porównuje go $\mathrm{z}$ wartością graniczną w odpowiedniej klasie niezawodności, np. $\beta \cong 3,8$; niezadowalający wynik wymaga zmiany wartości parametrów decyzyjnych (szerokość fundamentu, głębokość posadowienia i in.).

Warunkom obliczeniowym ULS w Eurokodzie 7 powinny towarzyszyć proste programy komputerowe (arkusze kalkulacyjne) wyznaczające wartość wskaźnika niezawodności $\beta$, do pobrania ze strony internetowej PKN lub może PKG.

Należy podkreślić, że to podejście jest całkowicie zgodne z wytycznymi PN-EN 1990, nie używając kontrowersyjnych częściowych współczynników bezpieczeństwa. Nie stanowi tutaj żadnego problemu, gdy parametry geotechniczne występują po obu stronach warunku obliczeniowego ULS - w obciążeniach/oddziaływaniach $E$ oraz w nośności $R$ - ponieważ warunek ten ma i tak ogólną postać funkcyjną $g\left(X_{1}, \ldots\right.$, $\left.X_{n}\right)=0$.

Warunek stanu granicznego powinien być w postaci jawnej uzupełniony o współczynnik modelu $\gamma_{\text {mod }}$ jako dzielnik do nośności $R$ - zazwyczaj zapewne większy od 1, ale w niektórych sytuacjach mógłby być mniejszy od 1, jeśli uproszczony model obliczeniowy pomija kilka korzystnych czynników stabilizujących (np. wytrzymałość gruntu zasypowego powyżej poziomu posadowienia ławy fundamentowej, rys. 1) lub jeśli projektowany obiekt ma funkcjonować przez krótki czas. Model FORM nie wymaga znajomości łącznych rozkładów prawdopodobieństwa (ang. distribution-free), o których niewiele wiadomo w projektowaniu geotechnicznym, ale wymaga znajomości wartości oczekiwanych, odchyleń standardowych i współczynników korelacji; w praktyce, te trzy ostatnie muszą być zastąione estymatorami, tj. wartościami skorygowanymi w zależności od liczebności populacji danych, jakości rozpoznania podłoża oraz przy uwzględnieniu efektu uśredniania fluktuacji pola losowego (współczynnik $\Gamma$ Schneidera redukujący odchylenie standardowe).

\section{Po drugie:}

Pozostawienie obecnej sytuacji, w której podejście DA2* jest rozsądnym kompromisem, choć narusza ogólne założenia Eurokodów i wprowadza stałe współczynniki bezpieczeństwa $\gamma_{R}$, które tak naprawdę stałe nie są; brak jest możliwości uwzględniania wielu czynników (kategoria geotechniczna, rozrzut wartości danych, konsekwencje awarii, okres funkcjonowania projektowanego obiektu itp.); do warunku GEO na wypieranie podłoża ogólny wskaźnik stateczności można szacować jako $\gamma_{o}=\gamma_{E} \cdot \gamma_{R}=\sim 1,4 \cdot 1,4 \cong 2$, co jest wystarczające.

\section{Po trzecie:}

Podstawową techniką mediacyjną przy braku konsensusu jest „,cofnięcie się o jeden krok”.

W przypadku Eurokodu 7 w ujęciu pół-probabilistycznym z częściowymi współczynnikami bezpieczeństwa modele obliczeniowe do wszystkich trzech rekomendowanych podejść obliczeniowych DA są już niemal na najniższym poziomie i cofnięcie się na niższy poziom oznacza tylko jedno: metodę ogólnego współczynnika bezpieczeństwa.

Przemawia za tym przedstawiona $\mathrm{w}$ niniejszej pracy analiza warunku DA2 ${ }^{*}$ dla $\gamma_{o}=\gamma_{E} \cdot \gamma_{R}$, gdy od razu rozwiązuje to kilka paradoksów modeli obliczeniowych ULS (rys. 1 i 2). Co więcej, takie modele obliczeniowe współcześnie istnieją (jakby obok Eurokodów) i to z dobrym skutkiem. Chodzi np. o niemieckie wytyczne projektowania konstrukcji z użyciem gruntów zbrojonych (Deutsche Gesellschaft für Geotechnik, 2011). 
Czy oznacza to cofnięcie kalendarza do czasów prof. W. Wierzbickiego i wcześniejszych? Rzeczywiście, przypomina się koncepcja naprężeń dopuszczalnych $R_{k} / E_{k}>\gamma_{o}>1$, z tym że obecnie istnieja lepsze możliwości faktoryzacji $\gamma_{o}$ za pomoca kalibracji i metod teorii bezpieczeństwa budowli - ISO 2394:2015(E), PN-EN 1990, PN-EN 1991. Takie podejście nie narusza założeń Eurokodów w stopniu większym niż DA2*. Propozycja faktoryzacji mogłaby opierać się na dziesięciu ,cząstkowych współczynnikach bezpieczeństwa" $\gamma_{i}$, generalnie $\gamma_{i} \geq 1$ (choć niekoniecznie zawsze):

$$
\gamma_{o}=\prod_{i=1}^{10} \gamma_{i}>1
$$

$\gamma_{1}$ - wiarygodność metod obliczeniowych do wyznaczenia obciążeń/oddziaływań $G, Q, A$;

$\gamma_{2}$ - naturalny losowy rozrzut wartości obciążeń/oddziaływań $G, Q, A$;

$\gamma_{3}$ - imperfekcje wymiarowe (w geotechnice najczęściej $\gamma_{3}=1$ );

$\gamma_{4}$ - wiarygodność metod rozpoznawania i dokumentowania budowy podłoża, zakres badań, aparatura, liczba próbek;

$\gamma_{5}$ - złożoność budowy geologicznej, naturalna losowa niejednorodność podłoża z uwzględnieniem efektu uśredniania (skali fluktuacji);

$\gamma_{6}$ - wiarygodność modelu obliczeniowego ULS, stopień uproszczeń, rezerwy nośności, mechanizmy zniszczenia, osłabienie/wzmocnienie ośrodka w stanie granicznym;

$\gamma_{7}$ - konsekwencje awarii geotechnicznej (klasy niezawodności): zdrowotne, społeczne, środowiskowe, ekonomiczne, odwracalne i nieodwracalne;

$\gamma_{8}$ - jakość wykonawstwa i kontroli, monitoring, wdrożona metoda obserwacyjna;

$\gamma_{9}$ - zmiany czasowe w okresie eksploatacji: efekty reologiczne, dynamiczne, starzenie (degradacja, korozja), progresywne zniszczenie, wzmacnianie się podłoża $\mathrm{w}$ trakcie budowy i po jej ukończeniu;

$\gamma_{10}$ - ewentualna korekta po uwzględnieniu doświadczeń porównywalnych.
Powyższa lista nie wyróżnia kategorii geotechnicznych, ale ich dwie składowe występują $\mathrm{w} \gamma_{5}$ oraz $\mathrm{w} \gamma_{7}$. Szczegółowe wartości współczynników $\gamma_{i}$, po ich doprecyzowaniu i wykalibrowaniu, byłyby stablicowane w EC7, zapewne w załącznikach krajowych i na ogół odrębnie dla każdego warunku obliczeniowego stanu granicznego.

Zdaniem autora dobry skądinąd pomysł zharmonizowania przepisów i zunifikowania procedur $\mathrm{w}$ ramach Eurokodu 7, ale przy jego nieco dogmatycznej realizacji, doprowadził do pewnej stabilnej sytuacji, jednak nie osiagnięto ani precyzji i jednoznaczności przepisów, ani konsensusu satysfakcjonującego wszystkie strony (kraje członkowskie).

Pomimo tych krytycznych uwag norma EC7 pełni niewatpliwie pozytywną funkcję i jest potrzebna. Korzystanie z EC7 w obecnej postaci podnosi niezawodność projektowania, choćby tylko na zasadzie sprawdzenia „checklisty”, wykorzystania różnych metod i doświadczeń porównywalnych do oceny parametru geotechnicznego, czy zalecania obserwacji konstrukcji i monitoringu powykonawczego. Sa to jednak cechy dobrego wykształcenia geotechnika lub szerzej - wykształcenia w zakresie geotechniki, a zatem raczej rola dobrego podręcznika, a nie normy do projektowania.

Nasuwa się pytanie: Jeśli nie Eurokod 7, to co w zamian? Przede wszystkim - nie tak dosłownie „W zamian”. EC-7 spełnia swoją funkcję, w tym sensie, że zgodne z nią projekty nie stwarzają zagrożenia. Wielokrotnie wykazywano w obliczeniach kontrolnych, że zapasy bezpieczeństwa czy wymiary konstrukcji otrzymywane na podstawie EC7 są zbliżone lub „bezpieczniejsze” niż według „starych norm krajowych" (być może są nawet za duże). Dodatkowo dokonywane na bieżąco aktualizacje normy, w miarę kolejnych zgłaszanych uwag z różnych krajów, podnoszą jakość tego dokumentu, a zmiana koncepcji i utworzenie trzeciej części EC7 mogą być znacznym postępem, pod warunkiem zachowania odpowiednich proporcji pomiędzy trzema częściami, większej uwagi poświęconej modelom obliczeniowym (wzorom) oraz przy właściwym podziale treści. Główne wątpliwości jednak pozostana, w tym niewyartykułowana rola czynników subiektywnych i ich wpływ na bezpieczeństwo. 


\section{PRAWDOPODOBNE KIERUNKI ZMIAN EUROKODU 7}

Rewolucyjnych zmian w Eurokodzie 7 nie należy się spodziewać.

Komitet CEN/TC250/SC7 prowadzi intensywne prace nad nowelizacją Eurokodu 7, współdziałając z krajowymi komitetami normalizacyjnymi, które zgłaszaja propozycje zmian i je opiniują. Praca nad zmianami ma bardzo dynamiczny charakter - pewne zmiany są proponowane, a zdarza się, że po kilku miesiącach konsultacji wycofywane. Dokumenty TC250/SC7 nie mają charakteru oficjalnego i nie na miejscu byłoby ich szczegółowe omawiane, ale ma sens przedstawienie prawdopodobnych kierunków podstawowych zmian:

1. Opracowanie trzeciej części Eurokodu 7, tj. EC7-3 (prEN 1997-3:202X. Geotechnical constructions) - zapewne znajdzie się tam więcej szczegółowych informacyjnych o projektowaniu (obliczaniu) pali, układów palowych i kotew, wzmacnianiu podłoża in situ, o konstrukcjach z gruntów zbrojonych, tunelach w gruntach i skałach, uwzględnianiu efektów dynamicznych, szerszym modelowaniu współpracy konstrukcji z podłożem, o odróżnianiu nasypów i wykopów w zagadnieniach stateczności i inne.

2. Gruntowne przeredagowanie (uproszczenie, skrócenie) istniejących dwóch części EC7-1 oraz EC7-2 - m.in. uniknięcie powtórzeń, faktów oczywistych i przeniesienie większości materiału do części trzeciej; nadal czynione są starania, aby pozostawić tylko jedno podejście obliczeniowe DA i proste wzory obliczeniowe do poszczególnych konstrukcji.

3. Dostosowanie Eurokodu 7 do zaawansowanych obliczeń numerycznych (obecnie najlepiej spełnia ten wymóg DA3), właściwe odwzorowanie faz budowy i pracy konstrukcji czy odpowiedni wybór modelu konstytutywnego.

Kierunki zmian są trafne, a szczególnie ten pierwszy; jak widać, planowane jest to dopiero za kilka lat. Powstała również inicjatywa opracowania zestawu wielu różnych przykładów obliczeniowych (wzorcowych), w formie oficjalnego załącznika do EC7-3, co na pewno poprawiłoby odbiór tej normy i niezawodność projektowania.

\section{PODSUMOWANIE}

1. Na bezpieczeństwo w geotechnice ma wpływ wiele różnorodnych czynników, począwszy od wstępnej fazy projektowej i rozpoznania budowy geologicznej i geotechnicznej podłoża aż po zmiany warunków gruntowo-wodnych na skutek zrealizowania inwestycji i monitoring powykonawczy.

2. Katastrofy budowlane - groźne w skutkach przekroczenie stanów granicznych nośności z przyczynami geotechnicznymi w tle - nie są częste, $\mathrm{w}$ przeciwieństwie do naruszenia stanów granicznych użytkowalności o kłopotliwych następstwach. Rzadko zdarza się, aby awaria budowlana miała tylko jedną przyczynę; groźne jest nakładanie się wielu przyczyn, czyli seria zaniedbań, naruszeń procedur i zwykłych błędów ludzkich. Wśród najgroźniejszych błędów dominują błędy elementarne, na poziomie wiedzy podręcznikowej - związane najczęściej z wodą gruntową i brakiem monitoringu.

3. Co by nie mówić o Eurokodzie 7, o jego „podręcznikowym stylu" formułowania zasad, to nawet samo wypunktowanie problemów jako „,checklisty" spełnia funkcję prewencyjna, choć ma poważnego antagonistę $\mathrm{w}$ postaci rutyny.

4. Można mieć liczne zastrzeżenia do niespójności norm geotechnicznych, obliczeniowych warunków sprawdzania możliwości wystąpienia stanów granicznych czy też rodzaju i wartości współczynników bezpieczeństwa, ale najważniejsze, że te przepisy zapewniają odpowiednie zapasy bezpieczeństwa. Głównych przyczyn awarii geotechnicznych należy upatrywać nie we wzorach i współczynnikach, ale w niewłaściwym lub niewystarczającym rozpoznaniu podłoża, które następnie skutkuje błędnym procesem interpretacyjnym, wadliwym przyjęciem parametrów do obliczeń, niewystarczającymi zabezpieczeniami obiektu oraz zaniżoną prognozą skutków oddziaływania obiektu na środowisko gruntowo-wodne (i odwrotnie).

5. Wprowadzanie do geoinżynierii nowych technologii, np. wzmacnianie podłoża rodzimego, czy nowych metod badawczych w badaniach terenowych i laboratoryjnych jest miarą postępu, zwiększa 
bezpieczeństwo w geotechnice, ale wymaga dużej ostrożności, wielokierunkowego, długotrwałego testowania i przebadania różnorakich ograniczeń.

6. Trwające prace nad gruntowną przebudową Eurokodu 7, a w szczególności wyodrębnienie trzeciej części (EC7-3) o charakterze konstrukcyjno-obliczeniowym, to na pewno krok we właściwym kierunku.

\section{PIŚMIENNICTWO}

Brząkała, W. (2013). Bezpieczeństwo i niezawodność w geotechnice. Kalibracja częściowych współczynników bezpieczeństwa według Eurokodu EC7-1. Inżynieria Morska i Geotechnika, 2, 118-124.

Brząkała, W. (2018). Zagrożenia i zabezpieczanie budowli. Aktualne problemy badawcze, wyzwania i realne możliwości. Inżynieria Morska i Geotechnika, 3 (przyjęty do druku).

Cichy, W., Lechowicz, Z. i Garbulewski, K. (2017). Eurokody jako europejskie normy zharmonizowane. W XXII Ogólnolskie Warsztaty Projektowania Konstrukcji, Wisła. T. 1. Wyktady (strony 21-32). Kraków: PZiTB.
Deutsche Gesellschaft für Geotechnik (2011). Recommendations for Design and Analysis of Earth Structures using Geosynthetic Reinforcements - EBGEO (Empfehlungen für Bewehrungen aus Geokunststoffen). Berlin: Wilhelm Ernst \& Sohn.

Kłosiński, B. (2013). Ocena i przyszłość Eurokodu 7 „Projektowanie geotechniczne”. Przeglad Naukowy - Inżynieria i Ksztaltowanie Środowiska, 60, 222-235.

Leonards, G.A. (red.) (1987). Dam Failures. W Proceedings of International Workshop on Dam Failures, West Lafayette. New York: Elsevier.

Orr, T. (2010). The Concepts of Eurocode 7 for Harmonized Geotechnical Design in Europe. Niepublikowany cykl wykładów na Wydziale Budownictwa Lądowego i Wodnego Politechniki Wrocławskiej, Wrocław.

Ratajczak, Z. (1988). Niezawodność człowieka w pracy. Studium psychologiczne. Warszawa: PWN.

Rosiński, B. (1978). Błędy w rozwiazaniach geotechnicznych. Warszawa: Wydawnictwa Geologiczne.

Wysokiński, L. (2007). Błędy systematyczne w rozpoznaniu geotechnicznym i ich wpływ na projektowanie budowlane. W Materiaty III Konferencji Naukowo-Technicznej „Awarie budowlane”, Szczecin-Międzyzdroje (strony 527-540). Szczecin: ZUT.

\title{
EUROCODE 7 AS AN ELEMENT IN THE SYSTEM OF STRUCTURAL SAFETY
}

\begin{abstract}
Various factors influencing the geotechnical safety of structures are discussed, starting from the concept phase, up to the post-implementation monitoring; the significant role of random aspects is emphasized. Assumptions, expectations and practical difficulties related to the use of the European code EN 1997 are presented, including the difficulty in applying the concept of partial safety factors. The planned edition of the third part of Eurocode 7 can significantly improve the quality of the code and therefore improve the reliability of geotechnical design.
\end{abstract}

Key words: geotechnical errors, geotechnical safety of structures, design approach, code updating 